\title{
Comparison of establishing SBAS approaches at uncontrolled airports (USA/Europe)
}

\author{
Miroslav Krch \\ Department of Air Transport, Faculty of Transportation \\ Sciences, Czech Technical University in Prgue \\ Horská 3, Praha 2, 128 03, Czech Republic
}

\author{
Jakub Kraus \\ Department of Air Transport, Faculty of Transportation \\ Sciences, Czech Technical University in Prague \\ Horská 3, Praha 2, 128 03, Czech Republic \\ e-mail: kraus@fd.cvut.cz
}

\begin{abstract}
This article focuses on comparing USA's and Europe's legislative attitude to establishing instrument approaches at uncontrolled airports. It tries to indicate the differences and the reasons which lead to these differences. The purpose is to identify things which are done correctly and should be followed as an example and, on the other hand, to recognize procedures which should not be followed and repeated.
\end{abstract}

Keywords-instrument approach, SBAS, IFR, VFR, uncontrolled airport, USA, Europe

\section{INTRODUCTION}

To follow good examples and learn from mistakes made by others has always been helpful in operating any company or business. If we talk about aviation industry and look at the area of instrument approaches at uncontrolled airports, USA can be the example for Europe. The reason is the 8 year long head start which United States has against Europe in using SBAS technology. 8 years in aviation industry is a really long time and therefore we can take a look what have they done good and what not.

SBAS technology has opened big possibilities in establishing instrument approaches at smaller airports without an operating control tower. Before this technology came into operation it wasn't easy to establish instrument approach at airports which didn't have any additional, and usually very expensive, ground equipment (conventional radionavigation aids as VOR, NDB, ILS etc.). Smaller airports are not likely to have enough money to acquire and maintain such an equipment. With the SBAS technology suddenly it is possible to establish instrument approach procedure with reasonable minimums without any other additional ground radionavigation equipment.

Once there is the technology to provide cheap instrument approaches, we can think of how to establish these approaches in as many places as possible. Many other studies have shown the increase in safety, if there would be more possibilities for diversion in case of weather deterioration. If the traffic level at these particular airports would remain reasonably low there is also no need to establish a control tower here (which would be very costly). But without a control tower we need to introduce special procedures for flying IFR to uncontrolled airports which would retain required safety.

\section{SitUATION IN THE USA}

Since the year 2003 the American SBAS system (WAAS=Wide Are Augmentation System) has been operational at the safety level which allowed the use in aviation industry for augmenting the instrument approach procedures. This is 8 years earlier than the European SBAS system EGNOS became operational at the same safety level in 2011. By that time (in 2011) there were already twice as many instrument approach procedures based on WAAS published in the USA than there were conventional ILS (Instrument Landing System) procedures throughout the whole United States. This quick growth shows the huge potential of this type of instrument operations.

The American aviation authority (FAA) is aware of this potential and invests a lot of effort in developing more and more WAAS-based procedures. FAA has actually set a goal of implementing 300 new WAAS-based procedures a year. This number should even be soon raised to a total of 500 new procedures annually. Even a funding program to support development of new WAAS-based procedures is established in the USA

Until the 17th of September 2015 there are 3567 LPV (Localizer Performance with Vertical guidance) approaches published at 1739 different airports all over the United States. 995 of these airports do not have any ILS approach published.

The tables below show the number of RNAV procedures published in the United States in a greater detail. 
TABLE I. NUMBER OF RNP APCH PROCEDURES IN US

\begin{tabular}{cccc}
\hline $\begin{array}{c}\text { Type of } \\
\text { approach }\end{array}$ & $\begin{array}{c}\text { Number of } \\
\text { published } \\
\text { procedures } \\
\text { (airport } \\
\text { certified } \\
\text { under Part } \\
\text { 139) }\end{array}$ & $\begin{array}{c}\text { Number of } \\
\text { published } \\
\text { procedures } \\
\text { (airport NOT } \\
\text { certified under } \\
\text { Part 139) }\end{array}$ & $\begin{array}{c}\text { Total } \\
\text { number of } \\
\text { procedures } \\
\text { published }\end{array}$ \\
\hline LNAV & 1767 & 4217 & 5984 \\
\hline LNAV/VNAV & 1374 & 2068 & 3442 \\
\hline LPV & 1380 & 2187 & 3567 \\
\hline $\begin{array}{c}\text { LPV with } \\
\text { decision }\end{array}$ & 629 & 301 & 930 \\
height of 200 & & & \\
ft & & 511 & 592 \\
\hline LP & 81 & & \\
\hline
\end{tabular}

TABLE II. NUMBER OF AIRPORTS IN US WITH RNP APCH

\begin{tabular}{lccc}
\hline $\begin{array}{c}\text { Type of } \\
\text { approach }\end{array}$ & $\begin{array}{c}\text { Number of } \\
\text { served } \\
\text { airports } \\
\text { certified } \\
\text { under Part } \\
\mathbf{1 3 9}\end{array}$ & $\begin{array}{c}\text { Number of } \\
\text { served airports } \\
\text { NOT certified } \\
\text { under Part 139 }\end{array}$ & $\begin{array}{c}\text { Total } \\
\text { number of } \\
\text { airports } \\
\text { served }\end{array}$ \\
\hline LNAV & 528 & 2190 & 2718 \\
LNAV/VNAV & 459 & 1187 & 1646 \\
LPV & 470 & 1269 & 1739 \\
\hline LP & 60 & 370 & 430 \\
\hline
\end{tabular}

Some of these airports are controlled, some uncontrolled. The procedure of implementing WAAS-based procedure on controlled airport is basically the same as implementing such a procedure at uncontrolled airport. But it needs to be verified that the infrastructure of the airport and its surroundings meet safety criteria.

In theory, WAAS-based procedure can be published to get the airplane down towards any runway. Turf runways are normally not compatible with instrument procedures but it is possible to get a Flight Standards approval. The factor which at the end decides whether the procedure can be established or not, and down to which minimums, is of course safety. In cases of shorter runways with worse surface it is necessary to do an individual case study and follow the safety principles.

The implementation process itself starts with the discussion between airport's sponsor (or the subject who is interested in implementing such a procedure) with the local FAA Airports Office, or state aviation agency. On the basis of the current approved Airport Layout Plan they discuss the changes that may be required for the airport to achieve the lowest possible minimums. Compliance with the design standards of Advisory Circular 150/5300-13 “Airport Design" is necessary. When they determine how low can the minimums be established and what changes need to be done for that, it is determined whether the changes are economic and feasible. If yes, the necessary data about the airport and its surroundings are being collected. Once collected, the airport sponsor or state aviation authority submits and official request for development of the procedure to the FAA. The request is reviewed by the Regional Airspace and Procedures Team (RAPT) and, if approved, the priority for publication is assigned and the development of the procedure is scheduled. All the data are then sent to the FAA's flight procedures group to Oklahoma City where the procedure is designed, checked and handed off for flight inspection.

At uncontrolled airports with instrument approach it is necessary to follow a procedure which would ensure safety and minimize the chance of mid-air collisions. It is practically impossible to let operate multiple airplanes flying under instrument flight rules (IFR) in one area without control of the ATC - this means, to let them operate in the vicinity of one airport without anybody on the radio who would provide separation between these airplanes (which might as well be operating inside the clouds).

The procedure called „ONE IN, ONE OUT“ has been developed in the United States for this kind of uncontrolled airports. This means that in one particular moment in the whole area might be only one airplane operating under IFR. It doesn't matter if it is arriving or departing.

There might be still a lot of VFR traffic operating around these airports during the time of IFR arrival or departure and the pilot of the IFR airplane needs to let everybody know about himself. For this purpose is used a designated frequency (CTAF $=$ Common Traffic Advisory Frequency) which is used and monitored by all traffic around that airport. All airplanes are making calls stating their positions and intentions on this frequency. This is the reason why people talk about these uncontrolled airports as of ,pilot-controlled airports“.

The airspace classification around these uncontrolled airports has very important role. At the most American uncontrolled airport with instrument approach procedure there has been airspace class E extended all the way towards the ground surface. It demands from all VFR traffic to maintain higher separation from the clouds and requires higher in-flight visibility. That provides more time to „see and avoid“ other traffic, especially the one that just popped out from the cloud layer on its instrument approach descent. 


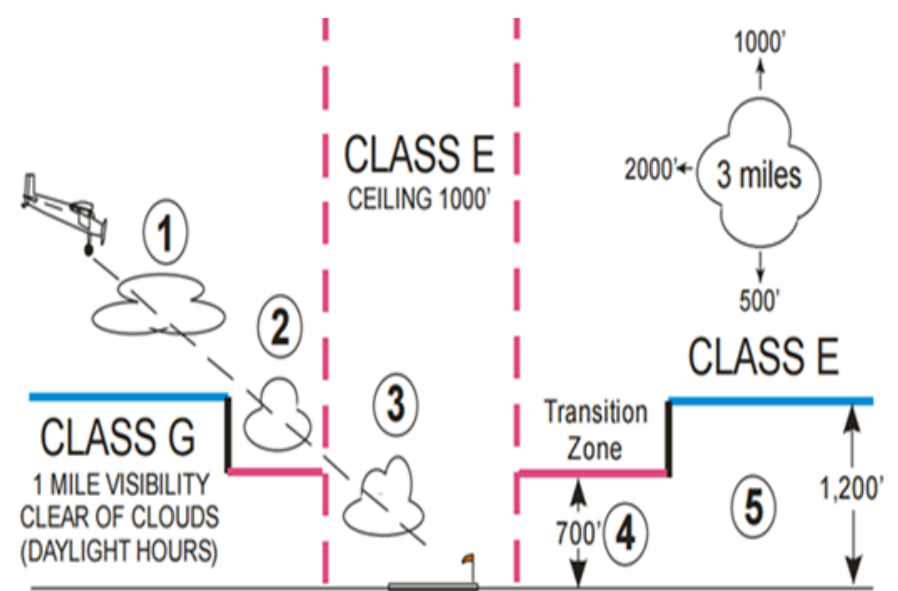

Figure 1. Airspace around some american uncontrolled aerodromes

In class $\mathrm{E}$ airspace the IFR traffic is controlled but the controller usually cannot see with his radar all the way down to the ground surface on the remote airport, so he simply clears the airplane for the approach, to change frequency to the CTAF and provides separation from other IFR traffic by not clearing anybody else towards the same area until he receives a call from the pilot of previous airplane that it is safely on the ground or is cancelling his IFR flight in VMC conditions still in the air.

For IFR departure from such an airport the controller talks with the pilot ahead of time and gives him a time period during which he is cleared to depart and simply makes sure that there will be no other IFR traffic during this time period.

But not all uncontrolled airports with instrument approaches in the US have the same airspace around them. Some have the airspace class E down only to $700 \mathrm{ft}$ AGL and class $G$ has been left underneath all the way to the ground surface.

At this kind of airports theoretically this situation could occur legally in the U.S.: If the actual minimum descent height of the implemented instrument procedure would be lower than these $700 \mathrm{ft}$ AGL there is a danger that the airplane on instrument approach will collide with some VFR traffic which is flying underneath the cloud layer (completely legally) in class $\mathrm{G}$ airspace staying just clear of clouds. In other words there is no time to see and avoid if the IFR traffic would popout of the cloud layer directly in front of the VFR traffic.

\section{SitUATION IN EUROPE}

During the past couple years European Union is trying to integrate the legislative processes throughout all EU countries. This is a very hard thing to do and no wonder that things sometimes work slower than people would wish. The slower legislative process in combination with the 8 year long delay behind the United States in using SBAS systems for augmenting instrument approaches is the reason why there are much less uncontrolled airports with instrument approaches than in the USA. Also the differences in regulations between individual countries do not help very much to the desired progress. There are visible differences in the amount of instrument approaches implemented in different countries of the EU. The table below demonstrates these differences.

TABLE III. IFR VS VFR AERODROMES IN EUROPE

\begin{tabular}{ccc}
\hline Country & $\begin{array}{c}\text { Total } \\
\text { number of } \\
\text { airports }\end{array}$ & $\begin{array}{c}\text { Number of airports } \\
\text { with instrument } \\
\text { approaches for civil use }\end{array}$ \\
\hline Czech Republic & 94 & 7 \\
Austria & 55 & 6 \\
Poland & 83 & 14 \\
Bulgaria & 29 & 5 \\
Slovenia & 18 & 3 \\
\hline Hungary & 80 & 7 \\
\hline Norway & 55 & 53 \\
Spain & 70 & 50 \\
Germany & 476 & 61 \\
\hline France & 450 & 151 \\
Italy & 98 & 47 \\
Great Britain & 127 & 65 \\
\hline
\end{tabular}

It is clearly visible that in some countries of EU the net of airports with instrument approaches is not dense enough. One of the reasons why these countries are behind with the use of SBAS system is the lack of agreement about the procedure and airspace around uncontrolled airports.

The American system of letting pilots control their movements around airports with instrument procedure is unacceptable in Europe. During the times of IFR operation somebody will have to be on the ground talking to the radio. It doesn't have to be an ATC controller, enough will be an AFIS officer providing just information service. There has been set a requirement for special airspace classification around such airports because airspace class $\mathrm{E}$ all the way down to the surface is not the way Europe legislation wants to go. The most probable outcome will be RMZ (Radio Mandatory Zone) where pilots will be obliged to have operational radio on board and to maintain constant two-way radio communication.

Another problem is that most of the uncontrolled airports have only turf runways. This is for now in Europe a great obstruction in instrument procedures implementation. Legislative organs do not allow these runways for instrument approaches or in other words don't want to cut down the requirements for runway parameters and equipment for instrument operations.

In this case would be a good idea to approach any request for instrument approach procedure implementation on a caseby-case basis and make a safety study for that particular airport which would decide how low minimums would it be possible to establish.

The ICAO resolution 37-11 provoked some higher activity in establishing SBAS-based procedures in Europe by setting timed milestones for implementation of these approaches at all instrument runway ends. The reason for that is increasing safety by creating back-up approaches for conventional procedures such as ILS. For now it doesn't help much in 
thickening the net of airports with instrument procedures but hopefully will the aviation authorities turn their attention towards uncontrolled airports soon after these milestones will be met.

\section{CONCLUSION}

This article shows the difference between Europe and the USA in development level of instrument procedures at uncontrolled airports. The delay in using SBAS systems, and the situation in Europe when the individual states are still not fully unified under one legislation, lead to the fact that IFR operations at uncontrolled airports are not that widespread yet as in the United States.

The attention should be paid more to the area of uncontrolled airports. The potential is great. Some modifications in the regulations will need to be done (maybe some document which would unify the requirements for airport and runway infrastructure would be helpful). On the example of United States is clearly visible that these operations can work safely and that the increased accessibility of airports from the air contributes to safety of smaller airplane operations and helps in economic growth.

The article also indicates the independence of European legislative. Not all procedures and airspace distribution in the US seem to be for $100 \%$ safe. Europe does a good job in creating its own methods and not following every procedure used in the US.

\section{REFERENCES}

[1] AIP Conline]. Available at: 〈http://lis.rlp.cz/ais_data/www_main_control/frm_cz_aip.htm>

[2] Guidance Material for The Implementation of RNP APCH Operations. [online]. EUROCONTROL, 2012. Available at:

$<$ http://www.paris.icao.int/documents_open_meetings/show_file.php?id $=1530>$

[3] Maximizing Airport Operations Using the Wide Area Augmentation System (WAAS) [PDF]. FAA. Available at:

<http://www.faa.gov/about/office_org/headquarters_offices/ato/service_ units/techops/navservices/gnss/media/maximizingairportoperationsusing waas.pdf>
[4] Satellite Navigation - GPS/WAAS Approaches [online]. FAA. Available at:

<http://www.faa.gov/about/office_org/headquarters_offices/ato/service_ units/techops/navservices/gnss/approaches/>

[5] Airspace explained [PDF]. West Wings Inc. Available at: 〈http://www.westwingsinc.com/AIRSPACE_EXPLAINED.pdf>

[6] Classes of Airspace [online]. AOPA Germany. Available at: $<$ https://aopa.de/ueber-uns/for-foreign-pilots/airspace/germanairspace.html>

[7] EGNOS User Support [online]. Available at: <http://egnos-usersupport.essp-sas.eu/new_egnos_ops/>

[8] Plos, V., Capoušek, L.: Processes on Uncontroled Aerodromes and Safety Indicators Part I. MAD - Magazine of Aviation Development. 2013, vol. 1, no. 5, art. no. 3, p. 11-15. ISSN 1805-7578.

[9] EUR RNP APCH Guidance Material (EUR Doc 025) [PDF]. ICAO, $2012 . \quad$ Available <http://www.pansa.pl/pliki/EUD_Doc_025_RNP_APCH.pdf>

[10] AIP Polska [online]. Available at: 〈http://ais.pansa.pl/aip/>

[11] AIP Austria [online]. Available 〈http://eaip.austrocontrol.at/index_new.php>

12] Procházka, J., Plos, V.: Aerodrome Flight Information Service. MAD Magazine of Aviation Development. 2013, vol. 1, no. 1, art. no. 4, p. 1518. ISSN $1805-7578$

[13] AIP Germany [online]. Available at: <http://www.ead.eurocontrol.int/publicuser/public/pu/login.jsp>

[14] IFR non-towered operations [online]. PilotEdge Training Center. Available at: <http://training.pilotedge.net/object/non-toweredoperations.html>

[15] SkyVector Aeronautical Charts [online]. Available at: $<$ https://skyvector.com/>

[16] ICAO RESOLUTIONS, ASSEMBLY - 37th SESSION, Provisional edition - November 2010 [online] Available at:

〈http://legacy.icao.int/icao/en/assembl/A37/Docs/a37_res_prov_en.pdf〉

[17] EGNOS Safety of Life, Service Definition Document [online]. Available at: <http://www.esspsas.eu/downloads/jcoes/egnos_sol_sdd_in_force.pdf>

[18] Pleninger, S.: The Testing of MLAT Method Application by means of Usage low - cost ADS-B Receivers. MAD - Magazine of Aviation Development. 2014, vol. 2, no. 7, p. 8-12. ISSN 1805-7578.

[19] ICAO Doc 9613 - PBN Manual [online]. Available at:

<http://www.ecacnav.com/downloads/PBN\%20Manual\%20 \%20Doc\%209613\%20Final\%205.10.08\%20with\%20bookmarks.pdf > 